\title{
Bebeklik ve çocukluk dönemine odaklanan araştırmacılar için yol haritası: Bilimsel çalışmalar için etik ve pratik öneriler
}

\author{
A roadmap for researchers focusing on infancy and childhood: \\ Suggestions for addressing practical and ethical issues in scientific studies \\ Gaye Soley ${ }^{1}$, Deniz Tahiroğlu ${ }^{2}$
}

\section{Makale Geçmişi \\ Geliş : 25 Temmuz 2019 \\ Düzeltme : 18 Aralık 2019 \\ Kabul : 19 Mart 2020}

\section{Makale Türü}

Derleme Makale

\begin{abstract}
Öz: Günümüzde oldukça ilgi çekici bir bilim alanı haline gelen gelişim psikolojisi alanında yapılan çalışmalar, hem kapsadıkları popülasyonların hassasiyetle ele alınmasının gerekliliği, hem de bu alandaki araştırmaların doğası ve işleyişi sebebiyle etik açıdan dikkat edilmesi gereken hususlar ve çeşitli zorluklar içermektedir. Bu alanda çalışan araştırmacılar ve öğrenciler için bir yol haritası oluşturması amacı ile kaleme alınan bu incelemede etik, bilimsel, ve pratik açılardan dikkat edilmesi gereken çeşitli noktalar gözden geçirilmiştir. Bu bağlamda, laboratuvar ve okul ortamlarında gelişimsel çalışma yürütme, öğrencileri çalışmalara asistan olarak dahil etme, katılımcı bulma, ve bilimsel bulguların halka ulaştırılması gibi konularda, hem katılımcıların esenliği hem de alandaki çalışmaların verimliliği ve sürdürülebilirliği açısından olumlu olacağı düşünülen önerilere yer verilmiştir.
\end{abstract}

Anahtar Kelimeler: Gelişim Çalışmaları, Bebeklik, Çocukluk, Araştırma Yöntemleri, Etik

Abstract: Developmental psychology is a popular area of scientific research that presents ethical and practical challenges due to the vulnerable populations it involves and the way in which studies in this area are conducted. This work aims to provide a roadmap for researchers and students working in this area. It reviews certain ethical, scientific and practical issues that need to be considered when conducting research with infants and children. To this end, this work presents suggestions for executing developmental studies in laboratories and schools, engaging students in assisting research, recruiting participants, and sharing scientific findings with the public. These suggestions aim to protect the wellbeing of participants' and to facilitate the productivity and sustainability of developmental studies.

Keywords: Developmental Studies, Infancy, Childhood, Research Methods, Ethics

${ }^{1}$ Boğaziçi Üniversitesi, Fen-Edebiyat Fakültesi, Psikoloji Bölümü gaye.soley@boun.edu.tr ORCID: https://orcid.org/0000-0002-6333-6017

${ }^{2}$ Boğaziçi Üniversitesi, Fen-Edebiyat Fakültesi, Psikoloji Bölümü deniz.tahiroglu@boun.edu.tr, ORCID: https://orcid.org/0000-0003-3871-8811 


\section{SUMMARY}

\section{Introduction}

Developmental research examines social, cognitive and physiological changes throughout the lifespan and has crucial implications for a wide range of fields from education to medicine. Although developmental psychology covers the entire lifespan, a substantial amount of research in the field focuses on infancy and early childhood, as these are the periods where we observe profound changes in social and cognitive domains. When concentrating on infants and children, who are considered vulnerable populations (National Institutes of Health, 1979), developmental psychology requires that researchers pay particular attention to ethical and practical matters. In this paper, we review ethical, scientific, and practical issues that pertain to the study of infants and children and offer suggestions for dealing with potential challenges.

\section{Ethical Issues}

This section will briefly cover issues pertaining to the ethics approval process, informed consent, incentives and feedback, and data storage and security. Being aware and mindful of the ethical issues will not only prevent potential problems but also help ensure the protection of participants and researchers alike. Regardless of the research question asked and the methods used, any study involving infants and children needs to go through an Institutional Review Board (IRB) review process. As in any research, parents of children participating in the study should be informed about the procedures, the costs and benefits of the study, and asked to sign an informed consent form. Families should be debriefed about the goals of the study, its hypotheses, and the expected results. If standardized measures are used in the study, the researcher may offer families feedback about the child's performance. All data should be kept securely in spaces that are accessible only to the researchers and assistants involved in the study. The privacy of the participants should be ensured at all times, including when sharing data with other researchers.

\section{Procedures}

Parents and children should feel comfortable when taking part in a scientific study. Therefore, when conducting research with children in laboratory conditions, the environment should be suitable for hosting families with children. All assistants involved in the study should undergo comprehensive training and be fully informed about the procedures and the scientific background of the study. The researchers should be flexible and try to accommodate families' needs.

In Turkey, it is possible to conduct research in school settings with the expressed permission of the Ministry of National Education (MNE). Just like the IRB application, the MNE should be informed about the goals, procedures, and the cost and benefits of the study. After receiving approval from the IRB, the MNE, and the school principals, the researchers should inform the parents about the study and ask for their informed consent. The school environment should be suitable for the execution of the study (e.g., a quiet area should 
be provided). Researchers should be respectful of students' class schedules and arrange their studies in collaboration with teachers so as to minimize disruption to class schedules.

\section{Involving Students in Research}

In order to maximize student assistants' work efficiency and to ensure that they learn as much as possible from their research experience, it is important that they be given extensive training. Graduate students working in the lab can also take part in the training of the undergraduates. To make this experience maximally beneficial for both researchers and the student assistants, the latter can be encouraged to commit a minimum number of hours per week - ideally for more than one academic term. In addition to being involved in practical activities such as data coding, student assistants should be informed about the theoretical basis of the studies — by encouraging them to attend and present at lab meetings, for instance.

\section{Participant Recruitment Strategies}

Recruiting participants for developmental studies can be challenging. Contacting schools is sometimes a good starting point for reaching out to families. In addition, institutions that provide services to infants and children (e.g., music schools), museums, hospitals and doctors' offices might be contacted for outreach purposes. Online platforms (e.g., lab official website and social media accounts) can also be utilized to advertise the study and recruit participants. To draw a sample from a more diverse population, researchers can use a variety of recruitment strategies, such as getting in touch with municipalities and NGOs that target these populations.

\section{Sustainability of Developmental Research}

It is crucial that families who participate in scientific studies have a positive experience. For this, both the researchers and their assistants should be considerate of the families' attitudes and be respectful of and responsive to their needs. In longitudinal research where participants will be asked to participate more than one time, it is crucial to keep in touch with the participants throughout the study and to remind them of their upcoming participation ahead of time. To increase participation when conducting research in schools, teachers and the principals could be asked to send out friendly emails to encourage families to participate in the research.

Recently, developmental researchers have started using online data collection strategies (e.g., Scott \& Shulz, 2017). Online data collection is relatively cheap, fast, and can be more objective (Birnbaum, 2004). However, it may not be suitable for all studies. Collecting data on sites where families can be reached easily (e.g., home settings, museums) is also an option. 


\section{Making Developmental Science Open and Accessible}

In addition to publishing findings in scientific journals, it is now common practice for researchers to share raw data and codes for analysis with others in order to improve the quality of science (Open Science Collaboration, 2015). It has also become common practice for researchers to preregister their studies and to engage in collaborative replication studies across labs in different parts of the world (Frank et al., 2017).

It is a professional duty of researchers to share scientific findings with non-psychologists (e.g., parents, teachers, policymakers). For this, it is critical that researchers write reports that summarize research findings using simple language that communicates the point without making it confusing for the reader (Pinker, 2015; Shtulman, 2018). Accurate portrayal of the findings is also important when communicating scientific findings to the public. 


\section{GİRİŞ}

Psikolojinin temel alanlarından biri olan gelişim psikolojisi, felsefe, sosyoloji, antropoloji, biyoloji, eğitim ve sağlık bilimleri gibi pek çok alanla etkileşim içindedir. Bu alandaki çalışmalar kapsamında yaşamın farklı evrelerindeki sosyal, duygusal, bilişsel ve fizyolojik gelişimin izlenmesi, insan zihnini ve davranışlarını daha iyi anlayabilmek, evrimsel süreçler hakkında perspektif kazanmak, iyi olma halini sağlamak adına önleyici programlar geliştirebilmek ve gerekli durumlarda (örn. atipik gelişim) müdahale edebilmek açısından son derece önemlidir. Bilimsel bir disiplin olarak 19. yüzyıl ortalarında ortaya çıkmış olan bu alan, aslında çok daha öncesinde de özellikle felsefi bir bakış açısı ile incelemelere konu olmuştur (Thompson, Hogan, ve Clark, 2012). Psikolojinin pek çok alt alanında olduğu gibi, bu alan da toplumsal ve teknolojik gelişmelerle birlikte hızlı bir değişim yaşamıştır. Çocukluğa bakışın değissimi (Corsaro, 1997), yeni metotların keşfedilmesiyle daha önceden araştırılması mümkün olmayan popülasyonların incelenebilir kılınması (örn. yeni doğmuş bebekler; Fantz, 1963) ve giderek yaygınlaşan disiplinler-arası bakış açısı sayesinde gelişim psikolojisinin diğer alanlardan da beslenir hale gelmesiyle (örn. diğer hayvan türleriyle yapılan karşılaştırmalı çalışmalar, bilgisayarlı modelleme, nörofizyolojik ölçümler) gelişim psikolojisi günümüzde oldukça popüler ve ilgi çekici bir alan haline gelmiştir. Gelişim psikolojisi, yaşam boyu gelişimi ele alan bir disiplin olmakla birlikte, çoğunlukla sosyal ve bilişsel birçok değişimin yoğun olarak gözlemlendiği yetişkinlikten önceki dönemlere odaklanan bir alan olarak korunmasız gruplarla da (örn. bebekler ve çocuklar) çalışmayı gerektirdiğinden (National Institutes of Health, 1979), etik açıdan dikkat edilmesi gereken hususlar ve çeşitli zorluklar içermektedir. Bu makalede, gelişim psikolojisi alanında bu tür popülasyonlarla araştırma yapılırken etik, bilimsel, ve pratik açılardan dikkat edilmesi gereken konular gözden geçirilecek, olası zorluklarla ilgili çeşitli çözüm önerileri sunulacaktır.

\section{ETİK KONULAR}

Bu bölümde, gelişim psikolojisi alanında yürütülen çalışmalarda dikkat edilmesi gereken etik konular ele alınacaktır. İnsanlarla araştırma yürütülen her alan gibi gelişim psikolojisi alanında da bu konuda bilinçli davranmak ortaya çıkabilecek etik sorunların önüne geçilmesi ve hem katılımcıların hem de araştırmacıların haklarının korunması açısından önem taşımaktadır. Bununla birlikte, bebek ve çocuklar korunmasız bir popülasyon olarak tanımlandığından (National Institutes of Health, 1979), bu popülasyonlarla araştırma yürütülürken ekstra hassasiyet gösterilmelidir. Burada kısaca ele alınacak bu konuya dair daha önceki kapsamlı çalışmalara da bakılabilir (Çakmak, 2018; Kumru, 2001; Say1l ve Yılmaz, 2001). 


\section{Etik Kurul Onayı}

Araştırmanın konusu ve yöntemi ne olursa olsun, bebek ve çocuklarla yürütülecek her araştırma, insanlarla araştırma yürütülen herhangi bir alanda olduğu gibi etik kurul onayından geçmelidir. Yalnızca gözlem yapılacak olsa dahi ilgili kurumlardan (örn. üniversite etik kurulu) etik izin alınmalıdır. Etik izin başvurularında çalışmanın amacı ve katkısına ek olarak yöntemler detaylıca anlatılmalı, çalışmalarda kullanılacak tüm materyaller (onam ve soru formları, kullanılacak uyaranlar), çalışma prosedürü ve katılımcılara ulaşmak için nasıl bir yol izleneceği bildirilmelidir. Ayrıca araştırmada hedeflenen katılımcı sayısı yaklaşık olarak belirtilmeli ve örneklem sayısının hangi kriterler esas alınarak belirlendiği (örn. güç analizi) ve dahil etme ve dışlama kriterleri de açıklanmalıdır. Araştırmada yer almanın katılımcı için ne gibi riskler içerdiği, ne gibi yararlarının olacağı da başvuruda detaylandırılması gereken konulardandır. Gelişim psikolojisi alanında bebek ve çocuklarla yürütülen araştırmaların içerdiği riskler genellikle gündelik hayatta karşımıza çıkan risklerden daha fazla olmamakla birlikte, bazı durumlarda ufak da olsa oluşabilecek riskler etraflıca düşünülmeli, varsa, bunlarla ilgili alınabilecek önlemlerle birlikte etik kurul başvurusunda belirtilmelidir. Örnek olarak bazı durumlarda, çocukların çalışma sırasında performans stresi yaşamaları, utanmaları ya da sıkılmaları beklenebilir. Bu durumlarda, örneğin çocuğun utangaçlığını azaltmak için çalışma öncesinde ebeveynin de olduğu bir ortamda araştırmacının katılımcı çocuk ile ufak bir ısınma aktivitesi uygulaması ya da oyun oynaması, çalışma izleğini çocuğun yaşına daha uygun ve daha çekici bir hale getirmek ya da çalışma süresini mümkün olduğunca kısa tutmak ve/veya görevler arası molalar vermek, eğer araştırmayı etkilemeyeceği düşünülüyorsa ebeveyni de çalışma sırasında aynı odaya almak gibi yöntemler uygulanabilir.

Bebek ve çocuk çalışmalarında katılımcılar aileleri de kapsamaktadır; onam formları aileler tarafından imzalanır ve ailelerden çocukları hakkında ve çeşitli demografik sorular içeren anketler doldurmaları istenebilir. Böyle durumlarda ailelere uygulanacak sorular da dikkatlice seçilmeli, hassas sorular varsa (örn. ebeveynlerin kendi aralanındaki iletişimle ilgili sorular) bu soruların sorulma nedenleri ve analizlerde nasıl kullanılacağı etik izin başvurusunda açıklanmalıdır.

\section{Bilgilendirilmiş Onam}

Etik kurul izni alındıktan sonra, çalışmada yer alacak çocuğun/bebeğin velisi/vasisi de katılmayı kabul ettiğine dair yazılı beyanda bulunmalıdır. Bunun için veli, araştırma hakkında genel bilgi ve araştırmacının isim ve iletişim bilgilerini içeren bilgilendirilmiş onam formunu okumalıdır. Bunun yanında veliye araştırmacı tarafından sözel olarak bilgilendirme yapılmalı, çalışma prosedürü açık ve net bir şekilde anlatılmalı, velinin soruları varsa sorması için uygun koşullar yaratılmalıdır. Daha 
sonra veliye formu okuması için yeterli zaman verilmeli, veli formu kafasındaki tüm sorular yanıtlandıktan sonra imzalamalıdır. Formun iki tarafın da imzalamıs olduğu bir kopyası araştırmacıda kalırken, bir kopya da veliye verilmelidir. Çalışma sırasında video ya da ses kaydı alınacaksa, formda açık olarak belirtilmeli, ayrıca bu video ya da ses kaydının nasıl kullanılacağı ile ilgili de detaylı bilgi verilmelidir. Kaydın tamamı ya da bir parçası, araştırma dışında, örneğin başka katılımcılar bulmak için laboratuvar broşüründe ya da web sayfasında, bilimsel amaçlı akademik konferanslarda ya da eğitim amaçlı derslerde kullanılacaksa, bunların her biri için veliden ayrıca izin alınmalıdır. İdeal durumda, veliden bu kayıtların farklı durumlarda kullanılmasını onaylayıp onaylamadığına dair onay alındıktan sonra, kaydın kullanılma durumu ortaya çıktığında veli ile iletişime geçilip tekrar sözlü onay alınmalıdır.

Katılımcı sözel onay verebilecek yaşta ise, katılımcı çocuktan da çalışmaya başlamadan önce onay alınmalı, çalışmayı bırakmak istediği anda ise, onay alınmış dahi olsa çalışma sonlandırılmalıdır. Ayrıca katılımcı çocuğun ya da velisinin çalısmadan herhangi bir neden belirtmeksizin istedikleri anda çekilebilecekleri, bunun herhangi bir olumsuz sonucunun olmayacağ1 ve bu durumda o ana kadar toplanan verilerin kullanılmayacağı onam formunda açık olarak belirtilmelidir.

Araştırma başlamadan etik kurul onayı almanın ve araştırmayı kurul tarafindan onaylandığı doğrultuda yürütmenin hem katılımcının hem de araştırmacının yararına olduğu unutulmamalıdır.

\section{Geri Bildirim ve Teşvik}

Çalışmanın ardından aile, katıldığı araştırmanın amacı, hipotezleri ve olası sonuçları hakkında bilgilendirilmeli, ailenin soruları varsa yanıtlanmalı ve aile ile araştırmacılar arasında bir yakınlık oluşturulmalıdır. Ailenin katılımının önemi vurgulanmalı, aileye ve mümkünse katılımcı çocuğa teşekkür edilmelidir. Çalışmanın ardından imkanlar dahilindeyse ailenin yol masrafları kısmen ya da tamamen karşılanabilir (örn. bir hediye çeki ile). Buna ek olarak katılımcı çocuğa yönelik bir hediye (örn. ufak bir oyuncak ya da kitap) verilmesi de önemlidir. Katılım sonrası verilen teşvik, çocuğun ya da ailenin üzerinde çalışmaya katılım için baskı oluşturacak kadar aşırı olmamalı, çocuğun performansından bağımsız olarak her katılımcıya verilmelidir. Araştırmalara katılım gösteren aileler bazı durumlarda psikolojik bir ölçüm ya da bebekleri/çocukları hakkında kişisel bir geri bildirim beklentisi içinde olabilmektedir. Bu tarz bir ölçüm yapılmayacaksa, geri bildirimin grup bazında olduğu açık bir şekilde aile katılım göstermeden önce belirtilmelidir. Şayet standardize ölçek(ler) kullanılıyorsa ve araştırmacıda bireysel değerlendirme yapılabilecek veri varsa, bunlar araştırma sonrasında sözlü ya da yazılı olarak aileyle paylaşılabilir. Ancak burada araştırmacının uygulamacı olarak da ehil olması ve sonuçları aileye en doğru şekilde aktarması önemlidir. Özellikle normların 
dışında performans gösteren katılımcıların ailelerine verilecek geri bildirim çok önemlidir (örn. dil testinde yaşının gereğinden daha düşük performans gösteren çocuklar için). Burada aileyi, olumlu ya da olumsuz, yanlış yönlendirmemek gereklidir.

Bununla birlikte çocukları konusunda hassas olan aileler çocuklarıyla ilgili sorulara yanıt verirken çocuklarının yaptığı ya da yapmadığı davranışları belirttiklerinde bundan kaygı duyabilirler, örneğin kafalarında "acaba benim çocuğum gelişim geriliği mi gösteriyor?” gibi soru işaretleri oluşabilir. Bu tür durumlarda araştırmacı, aileye bu soruların ne anlama geldiğini (örn. bu davranışların o yaş grubu çocuklarda bireysel farklılıklar gösterdiği) ve cevapların nasıl değerlendirileceğini açıklamakla yükümlüdür.

Ailelerin çalışmadan olumlu ayrılmaları, araştırmaya katılım bir defaya mahsus dahi olsa, gelişim psikolojisi alanındaki bilimsel araştırmaların devamlılı̆ı açısından ve araştırmacılar ile katılımcılar arasında güvene dayalı bir ilişki kurulması açısından son derece önemlidir. Araştırmanın tamamen bitmesinin ardından ailelere araştırma sonuçlarının anlaşılır bir dille anlatıldığı bir özet gönderilmesi de katılımcıların hem katkılarının önemini anlamalarına yardımcı olacak, hem de alandaki gelişmelerden haberdar olmalarını sağlayacaktır. Bu bağlamda, aile ile olumlu ve güven odaklı bir ilişkinin sürdürülmesi açısından ailenin katıldığı çalışmaya ek olarak, araştırmacı tarafından yürütülen farklı çalışmaların o güne kadarki sonuçlarını içeren bir doküman, yıllık bir bülten aracılığ1 ile katılımcı ailelerle paylaşılabilir (Ayrıca bkz. Gelişim Araştırmalarının Sürdürülebilirliği).

\section{Verilerin Saklanması ve Korunmas1}

Çalışmada elde edilen, katılımcıya ve ailesine ait verilere (yazılı dokümanlar, ses/video kayıtları) yalnızca araştırmacıların ve eğitimli asistanların erişimi olmalıdır. Veriler laboratuvarda, anahtarı sadece araştırmacılarda bulunan kilitli dolaplarda ya da şifresini yalnızca araştırmacıların bildiği bilgisayarlarda saklanmalıdır. Katılımcıların kimlik bilgilerinin gizliliğinin sağlanması adına kişisel bilgiler (örn. aileye ait ismin yer aldığı onam formları) çalışmada toplanan verilerden ayrı tutulmalı, veriler çocuk/aile ismiyle değil katılımcı numarasıyla kaydedilmelidir. Katılımcı bilgilerine tekrar tekrar ihtiyaç duyulan boylamsal çalışmalarda da (örn. katılımc1 6 ay ve 1 yıl sonra tekrar çalışmaya katılıma çağrılacaksa) katılımcı numarası ve aile bilgilerini eşleyen bir dosya tutulmalı, ancak bu dosyanın güvenliğine özen gösterilmelidir. Gelişim alanında çoğunlukla bireysel yanıtlardan ziyade katılımcıların ortalamaları rapor edildiğinden, aksi durumda, örneğin bir katılımcının kişisel video kaydı ya da ses kaydı farklı amaçlarla (örn. bilimsel sunum, ders) kullanılacaksa, daha önceden Bilgilendirilmiş Onam bölümünde de belirtildiği gibi, bunun için aileden ayrıca izin alınmalıdır. 
Psikolojinin pek çok alt dalında olduğu gibi gelişim psikolojisi alanında da ham verilerin ve hatta çalışma kayıtlarının diğer araştırmacıların kullanımına açılması gitgide yaygınlaşan bir uygulama olmaktadır (Open Science Collaboration, 2015). Açık Veri Portalı (Open Science Framework), Databrary, Mendeley gibi pek çok platform araştırmacıların verilerini farklı formatlarda paylaşmalarına olanak sağlamaktadır. Örneğin bu portallarda araştırmacılar sorulan anket ve mülakat sorularını ve/veya çalışma prosedürlerini görseller ve/veya videolar aracıllğıyla, toplanan verileri de farklı istatistik programları kullanarak paylaşmaktadır. Bu tür uygulamaların bilimsel gelişmeyi hızlandıran, bilimi daha şeffaf, bulguları daha tekrarlanabilir kılan olumlu özellikleri yadsınamaz. Ancak bu olumlu özelliklerin yanı sıra bu platformlarda yayımlanacak verilerin korunma esasları hususunda ekstra özen gerektirdiği de unutulmamalıdır; örneğin verilerin diğer araştırmacıların erişimine ne formatta açılacağına göre katılımcılardan ayrı izinlerin alınması gerekmektedir. Paylaşılan her türlü veride katılımcılara ait kimlik bilgilerinin olmadığından emin olunmalidir.

\section{PROSEDÜRLER}

Bu bölümde laboratuvar ve okul ortamında yürütülen araştırmalarla ilgili prosedürler gözden geçirilecek ve dikkat edilmesi gereken noktalar tartışlacaktır. Araştırmacıların karşılaşabilecekleri çeşitli zorluklar ve bunlarla ilgili önlem ve çözüm önerilerine değinilecektir.

\section{Laboratuvar Ortamında Veri Toplama}

Çocuk ve/veya bebeklerle yapılan çalısma laboratuvar ortamında yürütülecekse laboratuvar ortamının buna uygun olarak hazırlanması gerekmektedir. Bebekli ve küçük çocuklu ailelerle çalışmaların yürütüldüğü laboratuvarlarda elektrik prizlerinden mobilyalara kadar ortamda herhangi bir kazaya sebebiyet verebilecek durumlarla ilgili gerekli önlemlerin alınmış olması önemlidir. Ayrıca laboratuvar ortamının 1s1, havalandırma ve temizliğine özellikle dikkat edilmelidir. Laboratuvarda, çalışmanın yürütüleceği oda dışında ailelerin geldiklerinde ve çalışma sırasında vakit geçirebilecekleri bir odanın bulunması, mümkünse bu odaların birbirlerine bağlı olması ve ailenin çalışmaya katılan çocuğu izleyebileceği (kamera ve bilgisayar aracıllğıyla ya da tek taraflı ayna düzeneğiyle) teknik bir donanım olması idealdir. Birçok çalışma için çocukların görsel ve işitsel olarak dikkatlerinin dağılmaması, çalışma izleğini en doğru şekilde görmeleri ve duymaları önemlidir. Bu nedenlerle çalışmanın yürütüleceği odanın ses geçirmemesi ve odada çocuğun dikkatini dağıtacak başka nesneler bulunmamasina dikkat edilmelidir. 
Bunlar dışında aile ve çocuklar için yabancı bir ortam olan laboratuvarı hem çocukların hem de ailelerin kendilerini rahat hissedecekleri bir ortam haline getirmek önemlidir. Seçilen mobilya ve aydınlatma, kullanılan renkler çocuklara uygun olmalıdır. Çocuk ve ailelerin ihtiyaçları göz önüne alınarak laboratuvarda çocukların çalışma başlamadan önce vakit geçirebilecekleri oyuncak ve kitaplarla donatılmıs bir alan, ailenin çocuk çalışmaya katılırken onu izleyebileceği ve/veya form doldururken bulunabileceği bir alan, eğer laboratuvara çalışmaya katılan çocuk dışında başka bir çocuk (örn. kardeş) daha geldiyse onun da oynaması için bir alan ve onunla ilgilenebilecek ekstra bir asistan, bebekler için alt değiştirme/emzirme alanları bulunması idealdir.

Laboratuvarda yürütülecek çalışmalarda çalışmadan sorumlu olan tüm asistanların çok iyi eğitim almış olmaları, aileyle ilk randevulaşmadan ailenin laboratuvara gelişi, çalışma süresi ve çalışmadan ayrılmasına kadar geçen sürede neler yapmaları gerektiği konusunda etik ve bilimsel açılardan donanımlı olmaları gerekmektedir. Bunu sağlamak için verilen eğitimlerin yanı sıra laboratuvar ve çalışma prosedürleri ile ilgili bir el kitabı/kılavuz hazırlanabilir ve her aşamada kontrol edilmesi gereken noktaları içeren bir liste oluşturulabilir (örn. katılımcı gelmeden önce çalışmada kullanılacak tüm materyallerin hazır edilmesi, onam formlarının hazırlanması) (Ayrıca bkz. Asistan eğitimleri). Çalışmaya dahil olacak asistanların çocuk ve aileyle iletişimi iyi olmalıdır, bunu sağlamak için canlandırmalar yapılması ve pilot testler süresince asistanların araştırma yürütücüsü tarafindan izlenerek geri bildirim almaları önemlidir. Asistanların çalışmaya ve ilgili literatüre dair sorulara da yanıt verebilecek kadar bilgi sahibi olmaları gerekmektedir. Asistanların, görev aldıkları çalışmanın içeriğine ek olarak ailelerden gelebilecek farklı konulardaki sorulara nasıl yanıtlar vermeleri gerektiği konusunda da eğitilmeleri, aileleri yanlış yönlendirmemeleri adına önem taşımaktadır. Aynı zamanda acil durumlarda aranacak numaralar da asistanların elinin altında bulunmalıdır.

Yukarıda belirtilen ortamın sağlanması, ailenin, özellikle de katılımcı bebek ya da çocuğun çalışmaya katılmaya hazır durumda olması açısından önem taşımaktadır. Çalışmaya başlanmadan önce çocuğun ve velinin bir ihtiyacının olup olmadığı (örn. bebek açsa anne emzirmek isteyebilir) sorulmalı, varsa, aile bu ihtiyaç giderildikten sonra çalışmaya alınmalıdır. Bazı durumlarda çocuklar, yeni girdikleri laboratuvar ortamında araştırmacılarla iletişime geçmeye çekinebilmekte ve bu durum çalışmanın ilerleyişini de olumsuz şekilde etkileyebilmektedir. Bu nedenle, çalışmayı yürütecek araştırmacının çocukla çalışma öncesinde ebeveynin de bulunduğu bir ortamda oynaması ve çocuğun ortama ve araştırmacıya ısınması daha verimli bir çalışma gerçekleştirilmesini sağlayabilmektedir. Ĕ̆ger çocuğa uygulanacak birden fazla görev/test varsa testlerin sırası da çocuğun dikkatinin zamanla dağılma riski ve çalışmanın başında daha çekingen olabileceği göz önünde bulundurularak hazırlanmalıdır. Bu gibi durumlarda görevler arasında mola vermek 
ve/veya aralarda çocuğun kendini iyi hissedebileceği daha kolay ya da eğlenceli aktiviteler yapmak iyi olabilir.

Ailelere randevu verirken saatler konusunda esnek olmak önemlidir. Birçok aile için hafta sonları ya da akşam saatleri çalışmalara katılmak için daha idealdir. Bu saatler normal mesai saatleri dışında kalabileceğinden ailelerin randevularına sorunsuz gelmeleri için çalışılmalıdır; örneğin güvenlik ve ulaşımla ilgili olası sorunlar için önlemler alınmalıdır. Bebekli ailelerle yürütülen çalışmalarda bebeğin uyku ve beslenme saatlerinin günden güne farkl1lık gösterebileceği, dolayısıyla randevu saatlerinin değişebileceği göz önüne alınmalıdır. Ailenin randevuya gelememesi, geç kalması, ya da randevuyu farklı bir gün ya da saate almak istemesi gibi durumlarda, araştırmacıların bu tür durumları anlayışla karşılamaları, aileye herhangi bir olumsuz tutum sergilememeleri ve hatta onları rahatlatmaları çok önemlidir.

Laboratuvarın ortamı ile asistanların tutum ve konuya hakimiyetleri, gönüllülük esasına göre yürüyen gelişimsel araştırmaların sürekliliği açısından önem taşımaktadır. Ailenin olumlu bir deneyim yaşaması, sorularının yeterli bir şekilde yanıtlanması, ileride de bu alanda yapılacak araştırmalara katılma olasılığını artıracak, başka kişilerle bu olumlu deneyimlerini paylaşarak daha geniş bir katılımcı kitlesine ulaşılmasına yardımcı olacaktır. Laboratuvarda görev alan öğrencilerin/asistanların da bunun bilincinde olmaları bu açıdan son derece önemlidir.

\section{Okullarda Veri Toplama}

Okullarda yürütülecek çalışmalarda, etik onay alınmış olsa dahi, Milli Eğitim Bakanlığ1 (MEB) izni alınması gerekmektedir. Bu onay alınırken, etik kurul onayında olduğu gibi çalışma prosedürünün detaylıca anlatılması ve kullanılacak tüm materyallerin MEB'e sunulması gerekmektedir. İdeal olarak MEB izninin alınmasından önce çalışma yapılması planlanan okullarla iletişime geçilerek çalışmanın amac1, süresi ve prosedürü anlatılarak ön izin alınması sürecin daha olumlu ilerlemesini sağlamaktadır. Bunun mümkün olmadığı durumlarda etik kurul onayı ve MEB izinleri alındıktan sonra okul müdürleri ile iletişime geçilip çalışmanın amacı ve prosedürü açıklanmalı, uygun bulunduğu takdirde çalısmayı yürütmek için okuldaki öğretmenler ile birlikte hareket edilmelidir.

Etik kurul onayı, MEB izni ve okul onayı alınmasının ardından öğrencilerin aileleri ile iletişime geçilerek ailelerden de onay alınması gerekmektedir. Bunun için yüz yüze görüşme genellikle mümkün olmadığından çalısmanın amacı ve prosedürü aileye yazılı olarak sunulmalı ve aile bilgilendirilmiş onam formunu imzalayarak (ve okul yetkilisine ulaştırarak) velisi/vasisi olduğu çocuğun çalışmaya katılımına izin verdiğini belirtmelidir. Bu formu imzalamayan velilerin çocukları, 
üniversite etik kurul, MEB ve okul izinleri alınmış olsa bile kesinlikle çalışmaya dahil edilmemelidir. Bu aşamada sınıf öğretmenleri ya da rehber öğretmenlerin çalışma ile ilgili olumlu görüşleri ailelerin çalışmaya katılımlarını teşvik edici olabilmektedir. Dolayısıyla bu süreçte okul öğretmenleri ve yönetiminden de destek alınabilir (örn. ailelere gönderilen bilgilendirme ve hatırlatma e-postaları, veli toplantılarında yapılan duyurular). Çalışmanın nasıl yürütüleceği ile ilgili bilgilerin eksiksiz bir şekilde ailelere iletilmesi de bu süreçte önem taşımaktadır. Ailelere ve çalışmanın yürütüldüğü okullara çalışma sonunda çalışma sonuçları hakkında bilgilendirme gönderilmesi katılım oranlarını artıran bir unsur olmaktadır. Ailelerde olduğu gibi okullarda da olumlu bir izlenim bırakmak, çalışmanın yürütülmesi sürecinde öğretmenlere ve okul yönetimine mümkün olduğunca az iş bırakmak ve çalışmaları ders işleyişini mümkün olduğunca az aksatacak şekilde programlamak bu açıdan önem taşımaktadır. Bu bağlamda çalışmayı yürütecek araştırma asistanları da bu konuda bilinçlendirilmeli, okula gidecekleri gün ve saatleri sınıf/rehberlik öğretmenleri ile birlikte, onların uygun gördüğ̈ şekilde düzenlemelerinin ve okula hazırlıklı ve zamanında gitmelerinin önemi vurgulanmalidır.

Onayların alınmasının ardından çalışma mümkünse okuldaki sakin bir odada, ya da gürültüden uzak bir köşede yürütülmelidir. Çalışma süresi uzun olan çalışmaları okul ortamında yürütmek, derslerin aksamasına sebep olabileceğinden ideal değildir. Bu açıdan, süresi yarım saati geçmeyen çalısmalar okulda yürütmek için daha uygundur. Öğrencilerin araştırmacıya 1sınması için çalışma öncesi öğrenci ile kısa bir ısınma oyunu oynanması önerilir. Çalışmanın tamamlanmasının ardından çocuğa ufak bir hediye verilebilir. Bazı durumlarda ailesi katılmasına onay vermeyen öğrenciler, çalışmaya katılmış olan sınıf arkadaşları hediye aldığında üzülebilmektedir. Bu açıdan yapıştırma, oldukça sıklıkla kullanılan, çocukların hoşlandıkları, çalışmaya katılma izni olmayan çocukları da kapsayarak gerektiğinde tüm sınıfa dağıtılabilmesi açısından uygun bir hediyedir. Bunun dışında katılımcılara ve okullara teşekkür amaçlı olarak sınıflara kitap bağışı da yapılabilir.

Veri toplama ve analiz sürecinin tamamlanmasının ardından bulgular ailelerle ve öğretmenlerle paylaşılmak üzere okul yönetimi ile özet olarak paylaşılmalıdır. Bu özet, basit bir dilde yazılmalı, mümkünse anlaşılmasını kolaylaştıracak çeşitli figürlerle desteklenmelidir. $\mathrm{Bu}$ özetler gönderildiğinde, ailelere ve öğretmenlere destekleri ve katkıları için teşekkür edilmelidir. Bunlara ek olarak okullarda bulgularla ilgili bir bilgilendirme semineri de düzenlenebilir. Okullarda çalışma yürütüldüğü durumlarda, her sene aynı okullardan izin almak yerine farklı okullarla iletişime geçilmeli, ve aynı okula en az iki yılda bir sıra gelecek şekilde bir program oluşturmaya dikkat edilmeli, bu sayede okul çalışanlarının da bu süreçte yıpranıp olumsuz bir tutuma girmeleri önlenmelidir. 


\section{ÖĞRENCİLERİN ARAŞTIRMALARA KATILIMI}

Günümüzde pek çok öğrenci lisans döneminden itibaren araştırma laboratuvarlarında aktif olarak görev almaktadır. Bu tür deneyimler, hem öğrencilerin farklı bilimsel alanlar hakkında bilgi sahibi olmasını, hem de oldukça fazla iş yükü gerektiren çalışmaların aksamadan yürümesini mümkün kılarak öğrencilere ve araştırmacılara fayda sağlamaktadır. Bu deneyimin iki taraf açısından da veriminin artırılması için aşağıda çeşitli öneriler sunulmuştur.

Önceki bölümlerle bahsedildiği üzere, öğrencilere laboratuvar ve çalışmalarla ile ilgili detaylı bir el kitabı/kılavuz hazırlanarak bu kılavuzun, görev aldıkları proje ya da çalışmadaki rolleri ne olursa olsun, araştırma grubuna katılan tüm öğrenciler tarafından okunması yararlı olacaktır. Bu kılavuz, laboratuvarın tüm üyelerinin laboratuvarın işleyişiyle ilgili başvuracağı temel kaynak olarak hazırlanmalı ve gerektiğinde güncellenmelidir. Bu kılavuzda laboratuvarın genel kurallarına ek olarak (örn. giyim ve hijyen kuralları, çalışma saatleri), laboratuvarın düzeni (ne, nerede bulunur?), ailelerle telefon ya da e-posta ile iletişime geçildiğinde nasıl bir yol izleneceği, randevu oluşturma, veri tabanında arama yapma, aile ziyaretleri sırasında izlenen prosedür (örn. aileyi karşılama, bilgilendirme aşaması ve aileyi yolcu etme), detaylı çalışma ve veri saklama-yedekleme prosedürleri, ve laboratuvar içi iletişim kanallarının nasıl kullanılacağıyla ilgili bilgi içermelidir. Bunun yanında bu kılavuzlar akademik olarak da bilgilendirici olmalı ve laboratuvarda araştırılan konular ve bunların kuramsal önemi, güncel çalışmaların özetleri ve bu çalışmaların kapsadığı yaş grupları, ilerisi için planlanan çalışmalarla ilgili fikirler, laboratuvara dahil olan herkesin okuması gereken bir kaynaklar listesi gibi konuları da kapsayabilir. Ayrıca tüm laboratuvar çalışanlarından etik ve pratik olarak neler beklendiği bu kılavuzda açıklanabilir. Örneğin, yapılan çalışmalarda laboratuvar üyelerinin alacağı görevlerin net olması ve bu çalışmaların yayına dönüşüp basılması halinde kimlerin bu yayınlarda yazar olarak nasıl görevler üstleneceğinin herkes tarafından bilinip bu konuda hemfikir olunması sonradan ortaya ç1kabilecek sorunların önüne geçmek için iyi bir yöntem olabilir.

Lisans öğrencilerinin eğitilmesinde yüksek lisans ve doktora öğrencilerinin de görev alması, ve yüksek lisans ve doktora öğrencilerinin belli lisans öğrencilerinden sorumlu olması hem araştırma grubu üyeleri arasındaki ilişkilerin güçlendirilmesi, hem de yüksek lisans ve doktora öğrencilerinin süpervizyon deneyimi kazanmaları açısından olumlu olabilmektedir.

Özellikle gelişim alanında yürütülen araştırmaların ciddi bir eğitim süreci gerektirmesi nedeniyle, öğrencilerin bu eğitimden maksimum seviyede verim almaları, ve kendilerine verilen eğitimden faydalanmaları en azından bir akademik dönem, hatta mümkünse daha uzun süre çalışmalarını devam ettirmeleri ile mümkün olmaktadır. Bu bağlamda öğrencilere, kendilerinden en azından belli 
bir süre için laboratuvar çalışmalarına devam etmelerinin ve bu süre içerisinde her hafta belli bir süreyi bu çalışmalar için ayırmalarının bekleneceği iletilmelidir. Bu doğrultuda hem öğrencilerin ders programları hem de ailelerin çalışmaya katılım için uygunlukları göz önüne alınarak haftalık bir program oluşturulabilir (örn. her hafta sonu laboratuvarda en az iki öğrenci olacak şekilde program yapılabilir). Bunun yanında, asistan öğrencilerin katılımlarından daha fazla verim alabilmeleri için, katılımları çalışmalara yalnızca pratik anlamda yardımcı olmaları (örn. veri girişi ya da telefonla randevu verme) ile sınırlı kalmamalı, mümkünse farklı alanlarda deneyim edinmeleri sağlanmalıdır. Örneğin tüm çalışma ekibi olarak düzenli toplantılar yapılarak makale tartışmaları yapılabilir. Bu toplantılarda öğrencilerin de aktif katılımı cesaretlendirilmelidir. Öğrencilerden dönem sonunda çalıştıkları proje ile ilgili bir rapor hazırlamaları, poster sunumu yapmaları ya da laboratuvar toplantılarında makale sunumu yapmaları istenebilir. Bu tür deneyimler öğrencilerin yer aldıkları çalışmaların kuramsal değerini anlamalarına yardımcı olarak parçası oldukları araştırma grubuna bu anlamda da katkı sağlamalanını cesaretlendirecek, hem öğrenciler hem de araştırmacılar açısından daha verimli ve zengin bir eğitim ve araştırma süreci yaşanmasını sağlayacaktır.

\section{KATILIMCILARA ULAŞMA STRATEJİLERİ}

Yetişkin çalışmalarında katılımcılar çoğunlukla üniversite öğrencilerinden oluşmaktadır ve çalışmalara katılım karşıllğ̆ derslerde ekstra kredi almak isteyen öğrenciler bulmak nispeten kolay olmaktadır. Ancak bebek ve çocuklarla yapılacak çalışmalar için durum farklıdır. Özellikle yaş aralı̆̆ı kısıtlı çalışmalar için (örn. 7-9 aylık bebeklerin test edildiği bir çalışma) bu yaş aralığında çocuğu olan ailelere ulaşma ve aileyi çalışmaya katılım için ikna etme süreci zorlayıcı olabilmektedir. Yuvalar ve okullar/anaokulları ile iletişime geçmek ailelere ulaşmak için ilk başvurulan yöntemdir. Buralarda okul yönetimi ile iletişime geçilip çalışmanın velilere tanıtımı sağlanabilir. Bu, yazılı dokümanlarla olacağı gibi çalışma yürütücüsünün buralarda bir tanıtım toplantısı yapmasıyla da olabilir. Benzer şekilde bebek ve çocuklara hizmet veren okul dışındaki kurumlarla (örn. bebek ve çocukların gittikleri spor/müzik merkezleri), müzeler, hastaneler, sağlık ocakları, ve çocuk doktor ofisleri ile de iletişime geçilebilir. Ailelerin ve çocukların katıldığı etkinlikler (örn. çocuklar için hazırlanan açık hava eğlenceleri, piknikler) ailelere ulaşmanın bir yolu olabilir. Bazı araştırmacılar laboratuvar ortamında oyun grupları oluşturma gibi stratejilerin de başarılı olabildiğini rapor etmişlerdir (Brand, Gans, Himes, ve Libster, 2019).

Artık günümüzde çok yaygın olan internet de katılımcı bulmak için kullanılan mecralardan biridir. Çalışma tanıtımı için resmi hesaplar (örn. üniversite web sayfası, laboratuvar web sayfası) ya da laboratuvar sosyal medya hesapları kullanılabilir. Ayrıca çalışma tanıtımları için kullanılan resmi 
hesap sayfalarında ailelere iletişim formu doldurma opsiyonu sunularak bir veri tabanı oluşturulabilir (aileler kendi iletişim bilgilerini ve çocuklarının doğum tarihlerini, cinsiyetlerini girebilirler). Bu veri tabanları farklı yaş gruplarıyla çalışmaların yürütüldüğü laboratuvarlar için çok değerlidir. Bu veri tabanının kişisel verilerin gizliliği ilkesini ihlal etmemesi için bilgi-işlem ofislerinden destek alınabilir. Bu yöntemlere ek olarak, aynı kurum bünyesindeki farklı araştırmacılar arasında ortak bir sistem ve veri tabanı oluşturularak, farklı özelliklerde katılımcılar ile yürütülen çalışmalar için (örn. belli yaş aralığında, prematüre, gelişimsel bozukluğu olan ya da birden çok dile maruz kalan çocuklar gibi) katılımcı havuzları farklı laboratuvarlar arasında da paylaşılabilir.

\section{Katılımcı Özellikleri}

Günümüzde, psikoloji alanındaki araştırmalarda genel olarak katılımcıların toplumun belli bir kesiminden geldiği konusu tartısılmaktadır. Psikoloji literatürüne hakim olan çalışmalarda katılımcıların 'batıll, eğitimli, sanayilesmiș, zengin ve demokrat' (Western, Educated, Industrialized, Rich and Democratic [WEIRD]) kesimden geldikleri belirtilerek (Henrich, Heine, ve Norenzayan, 2010) bunun çalışmaların dış geçerliğini zedelediği konusunda eleştiriler yapılmaktadır. Gelişim psikolojisi özelinde de durum çok farklı değildir; çalışmalarda genellikle daha çok bu ailelerin çocukları yer almaktadır (Nielsen ve Haun, 2016). Yakın zamanda yapılan tekrar (replikasyon) çalışmalarında orijinal çalışmada elde edilen bulguların farklı sosyoekonomik seviyelerden oluşan katıllımcı gruplarıyla tekrarlanamadığı gözlemlenmiştir (örn. Watts, Duncan ve Quan, 2018).

Eğer seçilen örneklemin toplumu temsil etmesi isteniyorsa farklı grupları da hedef alan bir katılımc1 bulma stratejisi izlemek gerekmektedir. Laboratuvar çalışmalarına katılım daha çok yüksek sosyoekonomik seviyedeki ailelerden olmaktadır. Bunun bir nedeni ulaşım ve vakit esnekliğidir. Farklı gruplarla çalışmak istenildiğinde ulaşım ve zamanlama ile ilgili ekstra esneklik göstermek gerekmektedir. Bu ailelere çalışmayı tanıtmak için okulların yanı sıra mahalle/köylerdeki muhtarlar, aile hekimleri, belediyeler, ve sivil toplum kuruluşlarıyla ortak çalışmalar yapılabilir. Bu ailelere yönelik çocuk gelişimiyle ilgili seminerler düzenlenmesi hem aileleri bilinçlendirmek hem de çalışmayı tanıtmak için önemli olabilir. Aileler 'gelişimsel bilimsel çalışma' kavramına aşina olmadıklarında, bu çalışmalardan ne bekleyeceklerini bilemeyebilirler. Bu nedenle çalışma tüm risk ve faydaları da açık olmak üzere ailelerin anlayacă̆ı bir şekilde aktarılmalıdır. 


\section{GELİŞİM ARAŞTIRMALARININ SÜRDÜRÜLEBİLİRLİĞİ}

Önceki bölümlerde de kısaca değinildiği üzere gelişimsel araştırmaların sürekliliği, bu araştırmalara gönüllü olarak katılan aileler sayesinde olmaktadır. Bu nedenle, gelişim alanında herhangi bir bilimsel araştırma yürütülürken ailenin esenliği esas alınmalıdır. Çalışma deseni ve örneklemi oluşturulurken araştırmacıların olduğu kadar katılımcı ailelerin verecekleri emek ve zaman göz önüne alınarak maliyet-fayda analizi yapılmalıdır. Bunun yanında, ailelerin katılımlarından mutlu ve tatmin olarak ayrılmaları son derece önemlidir. Bu bağlamda en önemli görev araştırmayı yürüten ve ailelerle iletişimde olan yürütücü ve asistanlara düssmektedir, ve asistanların da bu konularda en az yürütücü kadar bilinçli olmaları gerekmektedir. Yukarıdaki bölümlerde asistan eğitimlerinde nelere dikkat edilmesi gerektiği ve bu eğitimlerden nasıl daha fazla verim alınacağı konularında çeşitli önerilere yer verilmiştir. Genel anlamda bebekli ya da çocuklu ailelerle araştırma yürüten laboratuvarların, araştırma grubu öğrencilerden oluşsa dahi profesyonel bir tutum içinde olması, ailelerin de araştırmalara daha fazla güven duymalarını sağlamaktadır. Örneğin laboratuvarla iletişime geçildiğinde, gün içerisinde aileye geri dönüş yapılması, kullanılan dilin profesyonel olması gibi hususlar önem taşımaktadır.

Katılım devamlılı̆̆ının özellikle önem taşıdığı boylamsal çalışmalarda aile ile iletişimin koparılmaması adına çalışmanın ardından özel günlerde (örn. çocuğun doğum günü) ailelerle eposta, telefon ya da mektup yoluyla iletişime geçilebilir, ve çalışmayla ilgili bilgilendirme yapılmaya devam edilebilir. Ziyaret tarihlerinden belli bir süre önce hatırlatmalar gönderilerek ailelere programlarını ayarlamaları için süre tanınabilir. Bunun dışında aileler için düzenlenen çeşitli bilgilendirme seminerleri de aile ile ilişkinin kopmaması için uygulanabilecek stratejilerden birisidir.

Okullarda yürütülen çalışmalarda karşılaşılan genel bir sorun, MEB ve okul izni alınmasının ardından, aileye gönderilen onam formunun bazı durumlarda katılmak istememe dışında farklı sebeplerden (unutma, vakitsizlik) doldurulmamasıdır. Bu durum katılım oranında düşüşe sebebiyet vermektedir. Bunun önlenmesi adına okul yönetimi ve öğretmenlerle iş birliği içinde olunması, okul yönetimi tarafindan ailelere hatırlatma e-postaları gönderilmesi, ya da öğretmenlerin aileleri katılım için cesaretlendirmesi etkili olabilmektedir (ayrıca bkz. okullarda veri toplarken dikkat edilmesi gerekenler).

Yetişkinlerle yürütülen araştırmalarda sıklıkla kullanılan online veri toplama stratejileri günümüzde gelişim psikolojisi alanında da yavaş yavaş kullanılmaya başlanmıştır. Internet üzerinden veri toplamanın pek çok avantajı olabilmektedir. Örneğin daha hızlı, daha objektif ve daha ucuz bir şekilde veri toplanabilmesinin yanı sıra, bu tür yöntemler normalde ulaşılamayan kitlelere de 
ulaşılmasını sağlamakta, daha geniş ve daha kapsayıcı bir örneklem test edilmesine olanak vermektedir (Birnbaum, 2004). Yakın zamanda çeşitli gelişim laboratuvarlarının okul öncesi ya da ilkokul çağındaki çocuklarla yürüttükleri bazı çalışmalar online platforma aktarılmış ve bu şekilde veri toplanmaya başlanmıştır (örn. http://discoveriesinaction.org). Bu platform aracilığ1 ile aileler, online olarak randevu oluşturabilmekte, bilgilendirilmiş onam formunu okuyup imzalayabilmekte, çalışmaya evlerinden katıldıktan sonra online olarak bilgilendirilebilmektedir. Benzer bir çaba bebeklerle çalışan araştırmacılar arasında da görülmektedir (Scott ve Shulz, 2017; Semmelmann, Hönekopp ve Weigelt, 2017). Ancak bu tür yöntemlerin avantajları olmasının yanı sıra her çalışmanın doğasına uygun olmayacağı da göz önüne alınmalıdır.

Online veri toplama stratejilerine ek olarak çeşitli yöntemlerle ailelerin bulundukları yerlerde veri toplama uygulamaları geliştirilebilir. Bu amaçla halihazırda sıkça kullanılan bir yöntem ev ziyaretleridir. Araştırmacılar açısından oldukça zaman alan bir yöntem olmakla birlikte, bu yöntem ailenin doğal ortamında, daha rahat şartlarda katılımını sağladığından ve aile için maliyeti minimum seviyede olduğundan tercih edilebilmektedir. Ancak, bu yöntem de her çalışma için uygun olmayabilir. Örneğin bebeklerle yürütülen çalısmalardaki düzeneklerin farklı ortamlarda kurulumu her zaman mümkün olmayabilir. Bu gibi durumlar için gezici laboratuvarlar tasarlanabilir. Özellikle farklı sosyo-ekonomik düzeyden ailelere ulaşmanın kritik olduğu ve çalışmanın kontrollü bir ortamda gerçekleşmesi gereken durumlar için bu tür bir yöntem son derece verimli olabilir. Buna ek olarak, ailelerin halihazırda çocukları ile vakit geçirmek için gittikleri çeşitli ortamlar da bazı çalışmaların yürütülmesi için uygun olabilmektedir. Özellikle Kuzey Amerika'da gelişimsel çalışmalar sıklıkla bilim müzelerinde yürütülebilmektedir (Callanan, 2012). Müzelerin gürültüden uzak bir alanı bu tür araştırmalar için ayrılmakta ve her gün farklı araştırmacılara bu alanda ilgilenen aileler ile çalışmalarını yürütebilmeleri için firsat tanınmaktadır. Bu hem aile hem de araştırmacılar açısından son derece ideal bir durumdur, çünkü iki taraf için de daha az maliyetli olmaktadır. Ülkemizde de benzer uygulamaların yaygınlaşması faydalı olacaktır.

\section{GELİŞİMSEL BİLİMİN AÇIK VE ULAŞILABİLİR KILINMASI}

Psikolojinin pek çok alanında olduğu gibi gelişim alanında da bulguların bilimsel hakemli dergilerde yayımlanmasının yanı sıra çalışma materyalleri, ham veriler, analiz kodlarının diğer bilim insanları ile paylaşılması, bilimsel araştırmaların daha hızlı ilerlemesi ve daha güvenilir olması için önkayıtlı çalışmaların (preregistered studies) ve pek çok laboratuvar arasında ortak yürütülen geniş kapsamlı replikasyon/tekrar projelerinin (örn., The Many Babies) yürütülmesi son yıllarda hız kazanmıştır (Frank vd., 2017). Bu tür çabalar, gelişim psikolojisinin sürdürülebilirliği açısından da son derece 
önemli olup, ülkemizdeki gelişim laboratuvarlarının da bu tür büyük ölçekli akım ve projelere katkıda bulunması, araştırma örneklemlerinin batılı örneklemler ile sınırlı kalmaması açısından önem taşımaktadır.

Diğer yandan, yapılan çalışmaların bilimsel dergilerde, akademik kitaplarda yayımlanması kadar bu bilgilerin diğer paydaşlara (örn., aileler, öğretmenler, sosyal politika üreticileri) ulaşması da çok önemlidir. Bunun için çalışmaların sonuçlarını bilimsel dilden uzak ama çarpıtmadan yazabilmek önemli hale gelmiştir (bkz. Pinker, 2015; Shtulman, 2018). Bilimsel bulguların laboratuvarın dışına çıkarılarak doğru ve anlaşılır bir şekilde paylaşılması, araştırmacıların temel görevlerinden biri olmalıdır. Araştırmacıları bu bağlamda zorlu bir görev beklemektedir, zira bu alanda oldukça fazla yanlış bilgi, son derece hızlı bir şekilde yayılabilmektedir. Gelişim psikolojisi alanında ailelerin genel anlamda bilgilendirilmesi ve eğitilmesi, yalnızca gelecek nesillerin daha sağlıklı gelişmelerine katkıda bulunmakla kalmayıp gelişim psikolojisi alanındaki araştırmaların sürekliliğini de olumlu yönde etkileyecektir. Örnek vermek gerekirse, bebek ve çocukların tablet bilgisayar ya da televizyona maruz kalmalarının etkilerini inceleyen ekran süresi ile ilgili çeşitli araştırmaların sonuçları (örn. Cheung, Bedford, Saez de Urabain, Karmiloff-Smith, ve Smith, 2017) yanlış yorumlanarak paylaşıldığında, ya da bu konu ile ilgili bilimsel verilere dayanmayan yorumlar yapıldığında, bu, ailelerde bir kez ekran görse dahi çocuklarının bundan zarar göreceği inancına yol açabilmektedir. Bu durum, bu bilgiler ışığında ailelerin çocuklarını yanlış yönlendirmelerinin yanı sıra, ailelerin ekran içeren bilimsel araştırmalara katılım konusunda da çekincelerinin oluşmasına sebep olabilmektedir. Benzer şekilde aileler çeşitli ön yargılar sebebiyle farklı yöntemler kullanan araştırmalara (örn. beyindeki elektrik dalgalarını ölçen tümüyle zararsız EEG yöntemi) katılmaya çekinebilirler. Aileleri gelişim psikolojisi alanında yürütülen araştırmalar ve bu araştırmaların yöntemleri hakkında bilgilendirmek bu tür ön yargıların kırılmasına yardımcı olacaktır. Aileler ve araştırma grupları arasında halka açık ders ve seminerler ve popüler bilim kitapları ve dergileri aracılı̆̆ı ile bir köprü kurulmalıdır. Bunun için çeşitli sivil toplum kuruluşları ve belediyelerden destek alınabilir. Doğru ve güvenilir bilginin yaygınlaştırılmasında internet ve sosyal medyanın gücü de azımsanmamalıdır. Aşağıda, bilimsel bulguların daha basit bir dille diğer paydaşlara aktarımı sırasında dikkat edilebilecek konular özetlenmiştir.

Bilginin laneti (curse of knowledge), yani bir șeyi bildiğimizde karşımıqdakinin de onu bildiğini varsaymak, özellikle dikkat edilmesi gereken hususlardandır. Shtulman'ın (2018) belirttiği üzere akademik makalelerde kullanılan dil, terimler ve yazma formatı genel okuyucu kitlesinin alısı1k olduğu bir format olmadığı için okuyucuya yabancı ve takip edilmesi zor gelebilir. Akademik yazılarda sıkça kullanılan psikoloji alanına özgü ya da genel terimler bile genel okuyucu için zorlayıcı olabilir ya da 
farklı anlamlar taşıyabilir. Örneğin bir araştırmacı için deney ve kontrol grubu terimleri çok sıradanken, genel okuyucu kitlesinin bu terimleri nasıl algıladığını bilmemiz zordur (Shtulman, 2018, s.480). Bu durumlarda akademik yazılarda kavram ve olguları gerektiği kadar basit bir dille açıklayarak ve örnekleyerek anlatmak daha anlaşılır olabilir.

Bunun dışında akademik yazılarda dikkat edilen başka bir konu da kesinlik belirtmekten kaçınmaktır (Shtulman, 2018). Ancak bu, genel okuyucu kitlesi için zorlayıcı olabilir. Örneğin 'normal şartlar altında A grubunun B grubundan daha iyi yapmasina sılklkla rastlanır' demek yerine bunu daha basite indirgeyip 'genelde A grubu B'den daba iyi yapar' gibi bir ifade kullanılması bilginin anlamın kaybetmeden genel okuyucuya uygun hale gelmesine yardımcı olur. Akademisyenler için istisnaları bilinen durumlarda genellemeleri yazmak ne kadar zor olsa da bu, genel okuyucu için, en azından bazı konularda, daha iyi bir yöntem olabilir (Shtulman, 2018). Ancak bunu yaparken de bilimsel bulguyu mümkün olduğunca anlamını değiştirmeden aktarmaya dikkat edilmelidir.

\section{SONUÇ}

Bu makalede, mesleki deneyimlerden yola çıkılarak gelişim psikolojisi alanında bebek ve çocuklarla çalışan araştırmacıların karşılaşabilecekleri zorluklara dair çeşitli önerilere yer verilmiştir. Laboratuvar ve okul ortamlarında yürütülen çalışmaların daha verimli bir şekilde yürütülmesini sağlayacak konulara değinilmiş, bu bağlamda etik açıdan özen gösterilmesi gereken noktaların yanı sıra, asistan eğitimlerinde dikkat edilebilecek hususlar vurgulanmış, çeşitli katılımcı bulma yöntemleri önerilmiştir. Araştırmaların yürütülmesi sürecinde dikkat edilmesi gereken çeşitli noktalara ek olarak, araştırma bulgularının bilim camiası dışından kişilere ulaştırılması konusunun önemi de unutulmamalıdır. Daha önce vurgulandığı üzere, bu önerilerle yalnızca araştırmacıların daha verimli, daha iyi kalitede veri toplamaları değil, katılımcı esenliğinin iyileştirilmesine de katkı sağlanması hedeflenmiştir. Bu önerilerin bebek ve çocuklarla çalışmalar yürüten farklı alanlardan (örn. eğitim) araştırmacılar için de faydalı olacağı, genel olarak bu popülasyonlara odaklanan bilim alanlarındaki çalışmaların sürdürülebilirliği açısından da olumlu sonuçlar doğuracağı düşünülmektedir. 


\section{KAYNAKÇA}

Birnbaum, M. H. (2004). Human research and data collection via the internet. Annual Review of Psycholology 55, 803-832.

Brand, R. J., Gans, R. T. H., Himes, M. M. \& Libster, N. R. (2019). Playdates: A Win-Win-Win Strategy for Recruitment of Infant Participants. Infancy, 24, 110-115.

Callanan, M. (2012). Conducting cognitive developmental research in museums: Theoretical issues and practical considerations. Journal of Cognition and Development, 13, 137-151.

Cheung, C. H. M., Bedford, R., Saez de Urabain, I. R., A. Karmiloff-Smith, \& Smith, T. J. (2017). Daily touchscreen use in infants and toddlers is associated with reduced sleep and delayed sleep onset. Scientific Reports, 7:46104.

Corsaro, W. A. (1997) The sociology of childhood. Thousand Oaks, CA: Pine Forge Press.

Çakmak, Z. (2018). Çocukların katılımıyla yürütülen araştırmalarda etik. Türk Psikoloji Yazılar, 21, $30-37$.

Fantz, R. L. (1963). Pattern vision in newborn infants. Science, 296-297.

Frank, M. C., Bergelson, E., Bergmann, C., Cristia, A., Floccia, C., Gervain, J., . . . Yurovsky, D. (2017). A collaborative approach to infant research: Promoting reproducibility, best practices, and theory-building. Infancy, 22(4), 421-435.

Henrich, J., Heine, S. J., \& Norenzayan, A. (2010). The weirdest people in the world? Behavioral and Brain Sciences, 33, 61-83.

Kumru, A. (2001). Çocuklarla çalışan psikologlar için etik standartlar. Türk Psikooloji Dergisi, 16(48), 87-91.

National Institutes of Health. (1979). The Belmont report. 30 Nisan 2019 tarihinde https://www.hhs.gov/ohrp/sites/default/ files/the-belmont-report-508c_FINAL.pdf adresinden erişildi.

Nielsen, M., \& Haun, D. (2016). Why developmental psychology is incomplete without comparative and crosscultural perspectives. Philosophical Transactions of the Royal Society B: Biological Sciences, 371, 1-7.

Open Science Collaboration. (2015). Estimating the reproducibility of psychological science. Science, $349(6251), 943$.

Pinker, S. (2015). The sense of style: The thinking person's guide to writing in the 21 st century. New York, NY: Penguin Books.

Sayıl, M. \& Yılmaz, A. (2001). Gelişim psikolojisi araştırmalarında etik standartlar ve tartışılan sorunlar. Türk Psikoloji Dergisi, 16(47), 71-78. 
Scott, K., \& Schulz, L. (2017). Lookit (Part 1): A new online platform for developmental research. Open Mind: Discoveries in Cognitive Science, 1(1), 4-14.

Semmelmann, K., Hönekopp, A., \& Weigelt, S. (2017) Looking Tasks Online: Utilizing Webcams to Collect Video Data from Home. Frontiers in Psycholology, 8, 1582.

Shtulman, A. (2018). Communicating developmental science to nonscientists, or how to write something even your family will want to read. Journal of Cognition and Development, 19, 477485.

Thompson, D., Hogan, J. D., \& Clark, P. M. (2012). Developmental psychology in historical perspective. Malden, MA: Wiley-Blackwell.

Watts, T. W., Duncan, G. J., \& Quan, H. (2018). Revisiting the Marshmallow Test: A conceptual replication investigating links between early delay of gratification and later outcomes. Psychological Science, 29, 1159-1177. 